\title{
Gender Role Perception in Society and Attitude towards Women Managers in Bangladesh
}

\author{
ATM Jahiruddin ${ }^{1}$, Mir Sohrab Hossain ${ }^{1}$, Mehedi Hasan Md. Hefzur Rahman ${ }^{1}$ \& Shahanaz Akter ${ }^{2}$ \\ ${ }^{1}$ Business Administration Discipline, Khulna University, Khulna 9208, Bangladesh \\ ${ }^{2}$ Independent researcher, Business Administration Discipline, Khulna University, Khulna 9208, Bangladesh. \\ Correspondence: ATM Jahiruddin, Business Administration Discipline, Khulna University, Khulna 9208, \\ Bangladesh. E-mail: atmjahir@yahoo.com
}

Received: September 1, 2020

doi:10.5539/ijbm.v15n12p122
Accepted: October 11, 2020

Online Published: November 10, 2020

URL: https://doi.org/10.5539/ijbm.v15n12p122

\begin{abstract}
This study investigates employees' attitudes towards women managers in different types of organizations in the context of Bangladesh. Two groups of respondents - supervisors of the women managers and other employees who report to the women managers were selected for data collection through a multistage procedure. The study found that employees, on the whole, have an indifferent attitude towards women managers at the workplace. Among different aspects pertinent to women's leadership, the employees demonstrated a favorable attitude about the women managers' knowledge and skill, while the employees feel that maternity and other feminine issues make women less desirable in the managerial positions. As the differences were investigated among the respondents of different demographic groups, significant differences were found among various groups based on gender, age, and sectors of employment. However, no significant difference was found among the employees based on their reporting relation with (supervisor and sub-ordinate) the women managers.
\end{abstract}

Keywords: women managers, employees' attitude, leadership, and gender role perception

\section{Introduction}

Increasing women's participation in the workforce has been a key feature globally for the last few decades. In recent times, women's proportion in the workforce has increased so rapidly in the developed countries in recent years that according to a prediction of the Economist (2009) number of women in the labor force would surpass the number of male in the USA in near future. Reflection on this global trend can also be noticed in Bangladesh. Although the proportion of working women among the women of working age is still much lower in Bangladesh (36\%) compared to even some other developing countries (e.g. 67\% in East Asia), this rate is much higher than it was before the $90 \mathrm{~s}$.

Despite some significant achievements with regards to women's empowerment in Bangladesh during the new millennium, strong patriarchy is believed to be a key feature in this country where women are expected to assume the role of subordination to men (Sultana, 2010; Mostafa, 2005). At the workplace, ideally, "leadership" should though be attributed based on the capabilities; constraints, and performance records, "think manager, think male" (Aycan, Bayazit, Berkman, \& Boratav, 2012; Balgiu, 2013) remains as a global trend (Schein, 2001; Schein, Mueller, Lituchy \& Liu, 1996). The tendency of attaching the leadership role to masculinity can though be noticed to some extent in all societies; it is more common in the developing countries. Because of the low rate of education, lack of resources, social and religious taboos, and poor rule of law, patriarchy seems to have a much stronger hold in the developing countries, and, as a result, leadership roles are by default attached to masculinity (Dormekpor, 2015; Balgiu, 2013).

Alongside the momentum gained globally in the movements of women's empowerment and priorities of international development partners (both government and non-government) on this issue, a wide range of government initiatives have significantly increased women's participation at the workplace in almost all the sectors (Parvin, Ahsan, \& Chowdhury, 2004). Prevalence of this gender-biased attitude about leadership role at the workplace may force the top management to restrict managerial positions only for male, which might result in several detrimental effects on the organization's performance, employees' morale, and fair human resources practice. At the same time, such actions may seriously impede the implementation of the Government agenda of 
women's empowerment and women's inclusion in every social and economic sphere of the country. Therefore, from the viewpoint of the workplace as well as the society at large, it is imperative to know whether and to what extent gender-biased attitude about leadership prevails in the workplaces in Bangladesh.

In the backdrops of this prevalent social gender role perception, and at the same time, an increasing proportion of women in the workforce in Bangladesh in the last few decades, this study was carried out with the broad objective of investigating the attitude prevailing in the workplace towards the women managers, vis-à-vis women leadership. This phenomenon (attitude towards women leadership) was investigated as a way of having an understanding of whether and to what extent gender role perception (that women should undertake the role of subordination) prevailing in Bangladeshi society, is replicated in the workplace in this country.

Although the attitude towards women leadership in the workplace is largely affected by overall gender role perception in the broader social context, attitude toward women leadership among the employees may vary due to several factors such as- their age, gender, position in the organizational hierarchy, etc. As suggested by different studies (e.g. Khan, 2005), attitude towards women leadership may vary due to tradition and social acceptance of women's participation in sectors of employment (Oplatka, 2006). Therefore, alongside investigating overall attitude towards women leadership at the workplace, this study also investigated whether and to what extent this attitude varies based on gender and hierarchy of the employees and different sectors of employment.

\section{Background and Literature}

\subsection{Gender Role Perception and Its Nature in Bangladesh}

Many earlier researchers (Gelles, 1976; Dobash \& Dobash, 1979; Hornung, McCullough, \& Sugimoto, 1981; Kalmuss \& Straus, 1982) hold that historically men have access to and control over productive resources that led to the economic dependence of women on them. Due to this dependence, women are expected to assume the role of subordination to men. Feminist scholars (i.e. Tolman \& Wang, 2005; Raphael, 2000; Yllo, 2005) view patriarchy as a form of power by the virtue of which, as they argue, men instinctively try to establish and retain gender supremacy over female.

Although different theories describe different factors as the major cause for such gender role perception, this has been a much more widespread and intense in the socio-economic settings in the developing countries, including Bangladesh (Sen, Germain, \& Chen, 1994; Feldman, 2001; Chullen, Adeyemi-Bello, \& Vermeulen, 2017). Notwithstanding some significant achievements in the recent past, the picture of women's participation in education and employment in Bangladesh still remains dismal. Despite targeted government initiatives, girls' enrolment in school is much lower and their dropout rate is much higher than boys' (UNDP, 2013). Furthermore, the Millennium Development Goals progress report for Bangladesh (Bangladesh Planning Commission, 2011) indicates that among the students in tertiary education, only $28.26 \%$ are female. Female participation (of the age over 15 years) in the labor force is only $36 \%$ compared to $82.5 \%$ of male participation. Even in sectors that predominantly provide women's employment (such as the garment), women are mostly employed in low skilled jobs and are paid less than their male counterparts (Khan, 2005).

Due to poverty, low rate of education, and religious and cultural norms, patriarchy is deeply entrenched in these societies, and as a result, men (in these societies) have instinctive eagerness to assume the role of superiority over women.

\subsection{Measure of Attitude Towards Women Leadership at the Workplace}

As defined by the classical psychologists (i.e. Allport, 1935; Krech \& Crutchfield, 1948), attitude is a mental and neural state of readiness, organized through experience, exerting a directive or dynamic influence upon the individual's response to all objects and situations with which it is related. Attitude formation is related to numerous factors among which some mentionable factors are gender, culture, individual need, family and socio-cultural environment and institutions that surround individuals, learning process, etc. (Chullen, et al., 2017). However, attitude is not a static phenomenon, rather it is altered over time with the change of economic, social, cultural, and other broader contexts that surround an individual (Salancik \& Pfeffer, 1977). Campbell (1950) emphasized attitude as a response co-variation in response to a set of social objects. Thus people are more likely to exert favorable and unfavorable (hostile) behavior towards the object (or individual, group, event, etc.) about which they possess positive and negative attitudes respectively.

Although research evidence on attitude toward women leadership at the organizations is rare in the context of Bangladesh, substantial research efforts have been exerted on this issue in the other contexts. Quite a large array of instruments has been used to measure attitude towards women leadership in the organization, among which 
use of three scales has been found most common. The oldest and probably most extensively used among these three scales is Women As Managers Scale (WAMS) developed by Terborg, Peters, Ilgen, and Smith, (1977). Other scales that have quite frequently been used to evaluate this phenomenon are the Attitudes Towards Women As Managers (ATWAM) Scale developed by Herbert and Yost (1978) and the Attitudes Towards Women Managers scale developed recently by Aycan et al. (2012). However, a large number of studies (e.g. Güney, Gohar, Akınc1, \& Akınc1, 2006; Adeyemi-Bello \& Tomkiewicz, 1996; Preko, 2012) studies this or related issues have also used a "hybrid" scale combining two or more scales.

As mentioned earlier, there have been extensive uses of the WAMS in recent studies on evaluation attitudes of employees towards female managers (e.g. Sakalli \& Beydogan, 2009; Lewis, 2010; Arkorful, Doe, \& Agyemang, 2014). The WAMS was designed to measure general attitude towards female managers through asking for the opinions of the respondents on several issues such as intellectual capabilities of women; the desirability of women in managerial roles; perception of pregnancy and menstruation as hindrances or not; stereotypes of women's societal roles; and ambition and emotional stability of women. Considering the extensive use of this scale in recent studies, the current study also used this scale for measuring the issues under investigation. However, after a pilot survey, 2 items (out of 21 items) were dropped from this scale and 5 items were included from other scales. Thus, number of variables used to evaluate employees' attitudes at the workplace in this study was 24 .

Using these measures, this study investigated the attitude of the employees towards women managers and their attitude towards different dimensions pertinent to women's leadership in Bangladesh with particular reference to organizations located in the Khulna region in the country. As the research evidence suggests that attitude towards women leadership in the workplace may vary based on their demographic differences and sector of the industry, this study also investigated if there were any difference among the employees of the different demographic groups (age, education, and hierarchy) with regards to their attitude toward women managers.

The following hypotheses were used to investigate these differences:

$H_{I}$ : There are significant differences among employees working in different sectors in their overall attitude towards female managers.

$\mathrm{H}_{2}$ : There are significant differences among the employees of various age groups in their overall attitude towards female managers.

$H_{3}$ : There are significant differences in the attitude towards female managers between supervisors of women managers and the employees reporting to them.

$H_{4}$ : There are significant differences between male and female employees in their overall attitude towards female managers.

\section{Method}

This study was conducted in the organizations or organization units located in Khulna city (which is the third-largest city in Bangladesh located in the Southwestern part of the country) and the adjacent peri-urban areas. Data were collected from two groups of respondents, supervisors of women managers, and the employees reporting to the women managers from the organizations of different sectors (listed in table 1). From a single organization, two supervisors and 10 or a quarter of the total number of employees (whichever is smaller) were interviewed. Thus, a total of 524 interviews (44 supervisors and 480 subordinates) were conducted from 22 organizations.

A structured questionnaire, including 24 attitudinal statements, was used for data collection (listed in tables 1, 2, 3 , and 4). Each statement was measured on a 7 points scale where a score "7" indicates the highest level of agreement ("strongly agree") and a score "1" indicates the lowest level of agreement ("strongly disagree"), the midpoint score "4" indicates an "indifferent" (neither agree nor disagree) position.

\section{Discussion}

In line with the objective of the study, this section first presents the overall attitude of the respondents about women managers and the proportion of employees possessing different levels of attitude. Besides the overall attitude, this section also discusses employees' attitudes about different leadership aspects of women managers. At the same time, this section presents the finding of different attitudes of different employee groups on women managers. These differences are shown among the respondents of different genders, age groups, types of organizations (different sectors), and hierarchy (supervisor and sub-ordinates of women managers).

\subsection{Overall Attitude and Attitude about Different Aspects Pertinent to Women Leadership}


As has already been mentioned, attitude towards women leadership was measured with the 24 statements being rated on a 7 point scale. The total score obtained by an individual was divided by the total number (24) of items (statements) to calculate the mean $(\overline{\mathrm{X}})$ score of an individual respondent. This mean score has been used as the measure of the overall attitude of the respective individual respondent,

$$
\overline{\mathrm{X}}=\sum\{(\text { scores of } 24 \text { items }) / 24\}
$$

The grand mean $(\overline{\bar{X}})$ score has been used as the proxy of the overall attitude of all respondents and it was calculated by dividing the sum of mean scores of all respondents by their total number.

$$
\overline{\bar{X}}=\sum\{(\bar{X} \text { scores of all individual respondents }) / \text { number of respondents(n) }\}
$$

Based on these formulas, the overall attitude score (grand mean score) has been calculated as 4.78, with a standard deviation of 0.711. Ali, Khan, and Munaf (2013), based on WAMS score, classified favorableness of attitude by labeling $\overline{\mathrm{x}}$ score from 5.50 to the maximum (7.00) as Favorable attitude; $\overline{\mathrm{x}}$ score from 4.00 to less than 5.50 as Moderate or Indifferent attitude; and from the minimum (1.00) to less than 4.00 as Unfavorable attitude. According to this classification, employees' overall attitude about women's leadership found (4.78) can be identified as moderate or indifferent. About the distribution of total 524 respondents across various levels of attitude, 109 (20.8\%) showed favorable attitude, over half (28 654.6\%) of the respondents showed indifferent or moderate attitude, and the remaining quarter of the respondents (12 924.6\%) showed unfavorable attitude towards women leadership at the workplace.

Alongside the overall attitude, this study also analyzed employees' attitudes about different aspects or dimensions related to women's leadership in the workplace. To do that, the first-factor analysis was run with scores of each item (statement) given by each respondent to find out the grouping pattern of 24 items (statements). Factor analysis showed high reliability (Cronbach's Alpha 0.86, KMO 0.89) and resulted in the loading of 24 items under six broad factors. Seven items (statement), related to women's capacity of facing challenging situations and being assertive (when needed) at the workplace were loaded together under the first factor, which has been labeled as the "Assertiveness" dimension of attitude towards women leadership. Five statements, related to women managers' skill levels and ability to analyze the business situations were loaded together under the second factor, which has been labeled as the "Knowledge and skill" dimension of attitude towards women leadership.

Another five statements related to women's competence to assume the leadership role and their capacity to make meaningful contributions for the organizations were under together the third factor, which has been labeled as the "Leadership quality" dimension of attitude towards women leadership. Another set of five statements, related to hindrances women managers face in performing their jobs due to maternity and other feminine issues were loaded under the fourth factor, which has been labeled as the "Maternity and femininity" dimension of attitude towards women leadership. It was not possible to identify any clear pattern of the remaining two factors as only one item (statement) was loaded under each of them. The following section discusses employees' attitudes about these four dimensions about women leadership.

\subsection{Attitude towards Assertiveness dimension}

As has been mentioned earlier, seven items (statement) have been loaded under this factor. Through responding to these statements, sample respondents expressed their attitude about the aspects that are related to the capacity of the women managers of facing challenging situations and being assertive when needed at the workplace. Table 1 below shows the loading of the individual items to this factor and the overall score of this dimension:

Table 1. Attitude about "assertiveness" dimensions

\begin{tabular}{llc}
\hline Items/statements & $\begin{array}{c}\text { Factor } \\
\text { Loading }\end{array}$ & $\begin{array}{c}\text { Item } \\
\bar{X} \text { score }\end{array}$ \\
\hline It is less desirable for women than men to have a job that requires responsibility* & .603 & 4.78 \\
Challenging work is more important to men than it is to women* & .572 & 4.00 \\
Women cannot be assertive in business situations that demand it* & .684 & 4.58 \\
Women possess the self-confidence required of a good leader & .529 & 5.14 \\
Women are not competitive enough to be successful in the business world* & .705 & 4.80 \\
Women cannot be aggressive in business situations that demand it* & .530 & 4.26 \\
In a pressure situation, a women manager would be no more likely to break down & .469 \\
than would be a male manager. & & 4.00
\end{tabular}


Note. Scores of * items were reverse coded.

Table 1 above shows that out 7 statements in the assertiveness dimension, average scores of 6 statements are close to the indifferent position (between to 4 to 5), and the attitude score of only one item related to women's self-confidence is just above 5. The average score of this dimension is 4.51 which indicates that employees, on the whole, have an indifferent attitude about women's capacity (compared to males) face challenge and be assertive when needed.

\subsection{Attitude towards Knowledge and Skill Dimension}

Through responding to five statements loaded under the second factor, sample respondents revealed their attitude about women managers' work-related skills and their ability to analyze business situations. Table 2 below shows the loading of the individual items to this factor, their (individual items') and the overall score of this dimension:

Table 2. Attitude about "knowledge and skill" dimensions

\begin{tabular}{lccc}
\hline \multicolumn{1}{c}{ Items/statements } & Factor & Item \\
& Loading & $\bar{X}$ score & $\bar{X}$ score \\
\hline Women have the objectivity required to evaluate business situations properly & .434 & 5.18 \\
$\begin{array}{l}\text { Men and women should be given equal opportunity for participation in management } \\
\text { training programs }\end{array}$ & .549 & 5.80 \\
Women have the capability to acquire the necessary skills to be successful managers & .585 & .699 & 6.00 \\
Women bosses have limited technical and mechanical skills than the male bosses* & .696 \\
Women are less capable of learning mathematical and mechanical skills than are men* & 5.40 \\
\hline
\end{tabular}

Note. Scores of * items were reverse coded.

As can be seen from table 2, employees' attitude about different aspects related to knowledge and skill dimension was found favorable. The attitude of three out of five statements is favorable, while the attitude score of the remaining two is only above 5 , which is close to being favorable. These findings lead to an inference that employees believe that, compared to their male counterparts, women managers possess adequate knowledge and skills required to be a good manager.

\subsection{Attitude about "Leadership quality” Dimensions}

Another five statements related to women's competence to assume the leadership role and their capacity to make meaningful contributions for the organizations were under together the third factor, which has been labeled as the "Leadership quality" dimension. Table 3 below shows the loading of the individual items to this factor, their (individual items') and the overall score of this dimension:

Table 3. Attitude about "Leadership quality" dimensions

\begin{tabular}{llc}
\hline Items/statements & $\begin{array}{c}\text { Factor } \\
\text { Loading }\end{array}$ & $\begin{array}{c}\text { Item } \\
\bar{X} \text { score }\end{array}$ \\
\hline $\begin{array}{l}\text { On the average, women managers are less capable in contributing to an organization's } \\
\bar{X} \text { score }\end{array}$ & .552 \\
$\begin{array}{l}\text { overall goals than are men* } \\
\text { It is not acceptable for women to assume leadership roles as often as men* }\end{array}$ & .482 \\
$\begin{array}{l}\text { The business community should someday accept women in key managerial positions } \\
\text { Society should regard work by female managers as valuable as work by male } \\
\text { managers }\end{array}$ & .511 & 4.51 \\
It is acceptable for women to compete with men for top executive positions & .568 & 5.51 \\
\hline
\end{tabular}

Note. Scores of * items were reverse coded.

As can be seen from table 3, employees' attitude about different aspects related to Leadership quality dimension was found indifferent or moderate. Attitude scores of two out of five statements are favorable, while the attitude score of another statement is above 5. Attitude scores of less than 5 of the remaining two statements make the 
average attitude score of this dimension 5.14, which is close to being favorable. These findings lead to an inference compared to the male managers, employees' attitude about the leadership quality of the female managers is not very favorable.

\subsection{Attitude about "Maternity and Femininity" Dimensions}

The last dimension identified from factor analysis consists of the items (statements) that are related to employees' attitudes about the extent to which female managers have to encounter difficulties in performing their jobs due to maternity and other feminine issues. Table 4 below shows the loading of the individual items to this factor, their (individual items'), and the overall score of this dimension.

Table 4. Attitude about "Maternity and femininity" dimensions

\begin{tabular}{|c|c|c|c|}
\hline Items/statements & $\begin{array}{l}\text { Factor } \\
\text { Loading }\end{array}$ & $\begin{array}{c}\text { Item } \\
\bar{X} \text { score }\end{array}$ & $\begin{array}{l}\text { Factor } \\
\bar{X} \text { score }\end{array}$ \\
\hline $\begin{array}{l}\text { The issues of pregnancy and maternity do not make women less desirable } \\
\text { employees than men }\end{array}$ & .316 & 3.65 & \multirow{5}{*}{3.96} \\
\hline $\begin{array}{l}\text { Women would no more allow their emotions to influence their managerial } \\
\text { behavior than would men }\end{array}$ & .575 & 4.17 & \\
\hline $\begin{array}{l}\text { To be a successful executive a woman does not need to sacrifice some of her } \\
\text { femininity }\end{array}$ & .580 & 3.93 & \\
\hline $\begin{array}{l}\text { On the average, a woman who stays at home all the time with her children is a } \\
\text { better mother than a woman who works outside the home at least half time* }\end{array}$ & .492 & 3.95 & \\
\hline Cannot give priority to their work lives because of their family responsibilities. * & .307 & 4.07 & \\
\hline
\end{tabular}

Note. Scores of * items were reverse coded.

As revealed in table 4, attitude scores of three out of five items on this dimension are in the unfavorable region (score below 4.00) and scores of the remaining two items are just above this level. The overall score of this dimension (3.96) falls in the unfavorable region which leads to an inference about employees' belief that women managers' capacity to perform their job effectively is substantially hindered by their maternity and other feminine issues.

As has been mentioned earlier, apart from 22 items grouped in four factors above, two items were loaded alone under two different factors. The attitude score of both statements is at a moderate level. These two statements are about the intensity of women's ambition to be successful in business ("Women are not ambitious enough to be successful in the business world"; reversed coded; item score 4.89), and employees' ease of communication with the women managers ("Female bosses are easy to communicate with than the male bosses"; item score 4.34).

\subsection{Differences in Attitude among Various Groups of Employees}

Apart from evaluating the attitude of the employees in general about women's managers, this study has also investigated if there was any difference in this regard among the employees of a different group. This difference was investigated on the basis overall attitude score of each respondent. The following section discusses differences in attitude towards women managers among the employees of different age groups, sectors, gender, and hierarchy (superior or subordinate to the women managers).

\subsection{Differences among the Employees of Various Age Groups and Different Sectors}

As can be noticed from Table 5 below, sample respondents were divided into six age groups and five different sectors of employment. One way ANOVA was used to investigate differences of employees' attitudes towards women managers among the employees of different sectors and different age groups as there are more than two groups under each of these two grouping variables.

Table 5 below shows the results of ANOVA test run with the overall attitude scores of the employees of different sectors and age groups: 
Table 5. Results of ANOVA test of the attitude scores of the employees of different age groups and sectors

\begin{tabular}{|c|c|c|c|c|c|c|}
\hline \multirow{2}{*}{$\begin{array}{l}\text { Grouping } \\
\text { variable }\end{array}$} & \multirow[t]{2}{*}{ Groups } & \multirow[t]{2}{*}{ f } & \multirow{2}{*}{$\begin{array}{l}\text { Attitude } \\
\text { score of the } \\
\text { group }\end{array}$} & \multirow[t]{2}{*}{ SD } & \multicolumn{2}{|c|}{$\begin{array}{l}\text { Results of the } \\
\text { ANOVA test }\end{array}$} \\
\hline & & & & & F Stat. & Sig. \\
\hline \multirow{7}{*}{ Age } & 30 years and below & 137 & 4.48 & .98 & \multirow{7}{*}{5.81} & \multirow{7}{*}{0.00} \\
\hline & 31 years to 35 years & 147 & 4.74 & .79 & & \\
\hline & 36 years to 40 years & 82 & 4.90 & .88 & & \\
\hline & 41 years to 45 years & 58 & 4.73 & .80 & & \\
\hline & 46 years to 50 years & 42 & 4.84 & .95 & & \\
\hline & Above 50 years & 58 & 4.23 & .82 & & \\
\hline & $\mathrm{n}$ & 524 & & & & \\
\hline \multirow{6}{*}{ Sector } & Government \& admin & 86 & 4.30 & .85 & \multirow{6}{*}{19.62} & \multirow{6}{*}{0.00} \\
\hline & Financial organization & 181 & 4.84 & .87 & & \\
\hline & Health Sector & 102 & 4.60 & .95 & & \\
\hline & Education sector & 95 & 5.10 & .77 & & \\
\hline & private organizations & 60 & 4.04 & .66 & & \\
\hline & $\mathrm{n}$ & 524 & & & & \\
\hline
\end{tabular}

As can be seen in table 5, the employees were classified into six age groups and five sectors of employment. Concerning the difference among the respondents' various age groups in the overall attitude scores, ANOVA test results reveal that there is a significant difference in the attitude of the employees about women managers of different age groups ( $\mathrm{F}$ stat 5.81, P-value 0.00). Therefore, $H_{l}$ : there are significant differences among employees working in different sectors in their overall attitude towards female managers - has been accepted.

Alongside the overall differences among various age groups, paired comparisons of the attitude score were made among different groups with the help of post hoc analysis. The results of post hoc analysis show that this difference mainly comes from the youngest (below 30 years) and the oldest (above 50 years) age groups. Post hoc analysis suggests that, when compared one to one basis, the average score of each of these two groups varies significantly with all other groups at 0.10 significant level. On the other hand, no significant difference was found between the other four age groups in the paired comparison. These analyses, along with the lowest attitude scores of these two groups of employees (below 30 years and above 50 years), lead to an inference that very young and very aged employees possess a relatively unfavorable attitude toward the women managers.

Concerning the respondents (employees) of different sectors, attitude towards women managers has been much higher in the educational institutions with an average score of 5.10. Employees of Financial organizations (Bank and insurance) and health sector (public and private hospitals and clinics) also reveals relative high score (4.84 and 4.60 respectively). On the other hand, employees of various (miscellaneous) private organizations (ranging from small scale local firms to branch offices of multinational companies) and government administration and services organization revealed a relatively low level of attitude towards women managers (average score 4.04 and 4.30 respectively). ANOVA test results shown in table 6 suggest that there are significant differences among the respondents of different organizations ( $\mathrm{F}$ stat 19.62, P-value 0.00). Therefore, $\mathrm{H}_{2}$ : there are significant differences among the employees of various age groups in their overall attitude towards female managers - has been accepted.

Paired comparisons are made among different groups with the help of post hoc analysis show that apart from education sectors and financial sectors, there is a significant difference (at 0.10 significance level) in the attitude level of the employees of each sector with every other sector. Therefore, it can be concluded that employees' attitude towards women managers largely varies in the organizations of different types.

\subsection{Differences between Male and Female and between Supervisors and Subordinates of the Women Managers}

This study also investigated differences in the attitude towards women managers of the employees of different gender (male and female) and hierarchical positions (subordinate and supervisors). As there are two groups under each of these grouping variables, a t-test was used to investigate differences between these groups.

Table 6 below shows the results of the t-test: 
Table 6. Results of t-test of the attitude scores of the employees of different hierarchy and gender

\begin{tabular}{llllllll}
\hline $\begin{array}{l}\text { Grouping } \\
\text { variable }\end{array}$ & Groups & $\mathrm{f}$ & $\begin{array}{l}\text { Attitude } \\
\text { score of the } \\
\text { group }\end{array}$ & SD & DF & Results t-test \\
Hierarchy & Supervisor & 44 & 4.75 & 0.59 & & & sig \\
\hline & Subordinates & 480 & 4.66 & 0.92 & 522 & .656 & 0.512 \\
& $\mathrm{n}$ & 524 & & & & & \\
Gender & Male & 318 & 4.49 & 0.87 & & & \\
& Female & 206 & 4.92 & 0.87 & 522 & -5.61 & 0.000 \\
& $\mathrm{n}$ & 524 & & & & & \\
\hline
\end{tabular}

As can be seen in Table 6, the mean scores of 44 respondents, who are the supervisors of the women managers, are 4.75, and the mean score of 480 respondents, who are subordinates of the women managers, is 4.66. T-test results (calculated t-value .656 and sig. 0.512) suggests that there is no significant difference between the supervisors of the women managers and their subordinates in their attitude towards women managers. Hence, $H_{3}$ : there are significant differences in the attitude towards female managers between supervisors of women managers and the employees reporting to them - cannot be accepted.

Regarding the attitude of the employees of two gender groups, the average score of 318 male employees is 4.49 and the average score of 206 female employees is 4.92. T-test results (calculated t-value -5.61 and sig. 0.00 ) suggests that there is a significant difference between male and female employees in their attitude towards women managers. Hence, $\mathrm{H}_{4}$ : there are significant differences between male and female employees in their overall attitude towards female managers - has been accepted.

\section{Conclusion}

This study was carried out to investigate the attitude of the employees towards women managers. Although a large body of literature (as discussed in detail in the literature review section) general defiance to the women's leadership role in Bangladeshi society, this study finds a moderate level of attitude towards women managers at the workplace in this country. It can be noted in particular that employees' have a favorable attitude towards the knowledge and skills of the female managers. At the same time, attitude scores of the dimension related to the leadership quality of women managers were though, in the range of moderate or indifferent level, this score is very close to the favorable range. Attitude scores of these two dimensions reflect employees' perception of the women managers being comparable to the male managers in terms of their competence, and close to the male managers in terms of their leadership qualities. As opposed to these positive attitudes, this study found unfavorable attitudes about the effect of maternity and feminine issues on women's ability to make an effective contribution in the managerial roles. At the same time, women managers' capacity of being assertive and facing challenging situations has been rated relatively poorly by the employees.

Selecting sample (organizations and the employees) from only the Khulna region might be suspected to be inadequate to capture the diversity of social norms and attitudes about women leadership in the other geographic areas in Bangladesh and hence this aspect can be seen as a limitation of the study. However, this limitation is believed to have overcome to a large extent due to the large sample size selected from a wide range of sectors of employment, and hence it seems plausible that the findings of the study can be generalized in the broader context of Bangladesh.

For the sake of fair human resources practice, employees' motivation, and, most of all, organizations' benefit, managerial positions should be awarded based on set rules and regulations, performances, competence, and potentials of the employees, not based on their gender. On the other hand, this can also not be denied that general resentments or even negative attitudes towards the managers not only constrain their (managers') ability to make an effective contribution to the organization but also can cause employees' grievance and low morale which can be detrimental for the organization in many respects. This study identifies aspects related to women's leadership in the workplace where employees have an unfavourable attitude. At the same time, this study identifies employee groups (based on different demographic features) who possess a relatively unfavorable attitude about women managers. These findings can be useful in initiating appropriate policy measures to enhance acceptance of women leadership at the workplace and ensure high employee morale, congenial industrial relations, and, above all, fair human resources practice in Bangladesh. 


\section{Acknowledgments}

This paper stems from a research project funded by Khulna University Research Cell (KURC). We gratefully acknowledge Khulna University and KURC for funding the research project.

\section{References}

Adeyemi-Bello, T., \& Tomkiewicz, J. M. (1996). The attitudes of Nigerians toward women managers. Journal of Social Behavior and Personality, 11(5), 133-140.

Ali, U., Khan, A., \& Munaf, S. (2013). Attitudes toward women in managerial position in Pakistan: A comparative study. International Journal of Information and Education Technology, 3(3), 373-377. https://doi.org/10.7763/IJIET.2013.V3.301

Allport, G. W. (1935). Attitudes: A Handbook of Social Psychology. Worcester, Mass: Clark University Press.

Anderson, J. C., \& Gerbing, D. W. (1988). Structural equation modeling in practice: A review and recommended two-step approach. Psychological Bulletin, 103(3), 411-423.

Arkorful, H. K., Doe, F., \& Agyemang, C. B. (2014). Attitude of private and public sector employees towards female managers in Ghana. International Journal of Human Resource Studies, 4(3), 241-253. https://doi.org/10.5296/ijhrs.v4i3.6201

Aycan, Z., Bayazit, M., Berkman, Y., \& Boratav, H. B. (2012). Attitudes towards women managers: Development and validation of a new measure with Turkish samples. European Journal of Work and Organizational Psychology, 21(3), 426-455. https://doi.org/10.1080/1359432X.2011.557860

Balgiu, B. A. (2013). Perception of women as managers. The difference of attitudes between employees and non-employees. Procedia-Social and Behavioral Sciences, 330 -334. https://doi.org/10.1016/j.sbspro.2013.04.305

Campbell, D. T. (1950). The indirect assessment of social attitudes. Psychological Bulletin, 47(1), 1-17. https://doi.org/10.1037/h0054114

Chullen, C. L., Adeyemi-Bello, T., \& Vermeulen, E. (2017). A comparative analysis of attitudes towards women as managers in the US and Netherlands. Journal of Leadership, Accountability and Ethics, 14(2), 24-42. https://doi.org/10.1108/17468801111144067

Dobash, R. E., \& Dobash, R. (1979). Violence against wives: A case against the patriarchy (pp. 179-206). New York: Free Press.

Dormekpor, E. (2015). Poverty and gender inequality in developing countries. Developing Country Studies, 5(10), 76-102. https://doi.org/10.1080/09589236.2012.691650

Dunlop, C. (2010). Female power. e Economist-Women in the workforce. Retrieved from https://www.economist.com/briefing/2009/12/30/female-power

Feldman, S. (2001). Exploring theories of patriarchy: A perspective from contemporary Bangladesh. Signs, 26(4), 1097-1127. https://doi.org/10.1086/495649

Gelles, R. J. (1976). Abused wives: Why do they stay? Journal of Marriage and the Family, 38(4), 659-668.

Güney, S., Gohar, R., Akıncı, S. K., \& Akıncı, M. M. (2006). Attitudes toward women managers in Turkey and Pakistan. Journal of International Women's Studies, 8(1), 194-211.

Herbert, T. T., and Yost, E. B. (1978). Women as effective managers: a strategic model for overcoming the barriers. Human Resource Management, 17(1), 18-25.

Hornung, C. A., McCullough, B. C., \& Sugimoto, T. (1981). Status relationships in marriage: Risk factors in spouse abuse. Journal of Marriage and the Family, 675-692.

Kalmuss, D. S., \& Straus, M. A. (1982). Wife's marital dependency and wife abuse. Journal of Marriage and the Family, 277-286.

Khan, F. C. (2005). Gender violence and development discourse in Bangladesh. International Social Science Journal, 57(184), 219-230. https://doi.org/10.1111/j.1468-2451.2005.546.x

Krech, D., \& Crutchfield, R. S. (1948). Theory and Problems of Social Psychology, 251-252. https://doi.org/10.1037/10024-000 
Lewis, K. E. (2010). Then and now: A longitudinal study of attitudes toward women as managers. International Journal of Management \& Information Systems (IJMIS), 14(5), 23-30. https://doi.org/10.19030/ijmis.v14i5.10

Millennium Development Goals. (2012). Bangladesh Progress report. Retrieve from https://www.undp.org/content/dam/bangladesh/docs/MDG/2012\%20Report\%20MDG.pdf

Mostafa, M. M. (2005). Attitudes towards women managers in the United Arab Emirates: The effects of patriarchy, age, and sex differences. Journal of Managerial Psychology, 20(6), 522-540. https://doi.org/10.1108/02683940510615451

Oplatka, I. (2006). Women in educational administration within developing countries: Towards a new international research agenda. Journal of Educational Administration, 44(6), 604-624. https://doi.org/10.1108/09578230610704819.

Parvin, G. A., Ahsan, S. R., \& Chowdhury, M. R. (2004). Women empowerment performance of income generating activities supported by Rural Women Employment Creation Project (RWECP): A case study in Dumuria Thana, Bangladesh. The Journal of Geo-Environment, 4(1), 47-62.

Preko, A. (2012). Attitude of male employees toward female managers in selected organizations in Ghana. Researchers World, 3(3), 86-93. https://dx.doi.org/10.24001/ijels.2.5.1

Raphael, J. (2000). Saving Bernice: Battered Women, Welfare, and Poverty. Northeastern University Press.

Sakalli-Ugurlu, N., \& Beydogan, B. (2002). Turkish college students' attitudes toward women managers: The effects of patriarchy, sexism, and gender differences. The Journal of Psychology, 136(6), 647-656. https://doi.org/10.1080/00223980209604825

Salancik, G. R., \& Pfeffer, J. (1977). An examination of need-satisfaction models of job attitudes. Administrative science quarterly,.427-456. https://doi.org/10.2307/2392182

Schein, V. E. (2001). A global look at psychological barriers to women's progress in management. Journal of Social Issues, 57(4), 675-688. https://doi.org/10.1111/0022-4537.00235

Schein, V. E., Mueller, R., Lituchy, T., \& Liu, J. (1996). Think manager-think male: A global phenomenon? Journal of organizational behavior, 17(1), 33-41.

Sen, G., Germain, A., \& Chen, L. C. (1994). Population policies reconsidered. Health, Empowerment and Rights, 8-11.

Sultana, A. (2010). Patriarchy and Women Subordination: A Theoretical Analysis. Arts Faculty Journal, 1-18. https://doi.org/10.3329/afj.v4i0.12929

Terborg, J. R., Peters, L. H., Ilgen, D. R., \& Smith, F. (1977). Organizational and personal correlates of attitudes toward women as managers. Academy of Management Journal, 20(1), 89-100. https://doi.org/10.2307/255464

Tolman, R., \& Wang, H. C. (2002). Domestic violence and employment: Fixed effects models of three waves of women's employment study data. In Annual Conference of the Association for Public Policy Analysis and Management (APPAM), Dallas.

United Nations. (2013). UN in Bangladesh. Retrieve from https://www.undp.org/content/dam/bangladesh/docs/Publications/Pub-2014/UNDP\%20annual\%20report\%2 02013\%20to\%202014\%20FINAL\%20ONLINE\%20VERSION.PDF

Yllo, K. (2005). Through a feminist lens. Current controversies in family violence (pp. 19-34).

\section{Copyrights}

Copyright for this article is retained by the author(s), with first publication rights granted to the journal.

This is an open-access article distributed under the terms and conditions of the Creative Commons Attribution license (http://creativecommons.org/licenses/by/4.0/). 